\title{
Clitic -lah in Constructing Swear of Bengkulu-Malay Language
}

\author{
Eli Rustinar \\ Muhammadiyah University of Bengkulu \\ elirustinar@ymail.com
}

\begin{abstract}
Cliticss(clitics) -lah in Bengkulu-Malay Language (BMB) is a bound form which phonologically has its own pressure, can not be considered as a bound morpheme, has no word features, and is not bound to a particular word class. Clitics -lah tend to be enklitik. From the used of clitics -lah appear to tend to be attached to clause units.In Bengkulu-Malay Language (BMB) the researcher found many form of swears which are followed by clitics-lah (attached) then the researcher was interested to investigate the form, characteristic and the used of -lah in constructing swear of Bengkulu-Malay Language. The research method is qualitative in the form of writing data with the method of distributional study which is in line with theoretical understanding of Ferdinand De Saussure about his structural the whole unified theory. The source of the data comes from libraries reference which were derived from three(3) sources. They were: books (Tarino, 2008); article (Botifar, 2016); and electronic media (Facebook, 2017). Datas were clitics -lah in constructing swear of Bengkulu-Malay Language. Methods and techniques of data collection is done through the method of referring to writing techniques and methods of introspection by utilizing the language intuition of the researcher. Data analysis was done through agih or distributional method which used the basic language determinant device (power of dividing) and it also has a characteristic of lingual intuition. The result of the research showed that there were 15 data which used clitics -lah in constructing swear of Bengkulu-Malay Language. They were: Paju abarlah kau, Ditembak petuslah kau, Mati sepegaslah kau, Mati beranaklah kau, Mati berantulah kau, Paju guamlah mulut ambo, Paju rimaulah, jahanamlah kau, Masuk nerako jahanamlah kau, buncitlah perut kau makan hak anak yatim iko, Tekutuklah kau, Mampuslah kau cepek, Modarlah kau leke, Sumpah dipaju gerindinlah kau, Terbang amburlah dari rumah iko.The form of -lah in constructing swear of Bengkulu-Malay Language always bound in another form of word, so it could be defined that -lah is not an afix and is also not a word but it is called as clitics because it could not stand alone by itself. The function of clitics -lah is as a displayer of substance which is in it word itself with the characteristics, such as: it could not stand alone by itself, it has no meaning, it is bound to the previous substance, it rises altogether with the form attached to itself and it has a position as enklitik, it also can be attached with more than one of word classes. The used of clitics -lah tend to be attached to the predicate of the sentence. The used of clitics -lah is as a pressure if it is attached to another word. In Bengkulu-Malay Language, the swear which is followed by clitics -lah become rougher and can give more pressure on the pronoun, so that it becomes more clearly the emphasis on the intended person.
\end{abstract}

Keywords-Swear, Bengkulu-Malay Language, clitics-lah, form, function, used

\section{INTRODUCTION}

Bengkulu Province is directly adjacent to the Indonesian Ocean on the coastline of approximately 525 kilometers, located on the west of Bukit Barisan mountain range with an area of approximately 1,991,933 hectares extending from the border of West Sumatra Province to the border of Lampung Province. Astronomically located between $2^{\circ} 16^{\prime} \mathrm{LU}$ and $3{ }^{\circ} 31^{\prime} \mathrm{LS}$ and between $101^{\circ} 01 \backslash^{\prime}-03^{\circ} 41^{\prime}$ BT geographically in the north, it is bordering to the Province of West Sumatra, in the south, it is bordering to Indonesia Ocean and Lampung Province, in the west, it is bordering by the Indonesian Ocean and in the east by Jambi Province and South Sumatera Province (Language Department, 2017)

The population of Bengkulu Province from BPS(Statistical Centre Department) data is 1874.9 people with in Bengkulu City's population is 351.3 people (Bengkulu, 2017). They have 9 (nine) regional languages namely, Mukomuko, Enggano, Rejang, Lembak, Bengkulu-Malay, Serawai, Mulak, and Pekal language. Geographically, Bengkulu-Malay language speakers live mostly in the coastal area of Bengkulu City and extend to the north and south (Hamidy, 2004, p. 7)

Bengkulu-Malay Language (BMB) has a position as a local language, regional languages, and ethnic languages. As a local language, it is bound to a limited area of Bengkulu City and is used daily; as a regional language, it is used as a daily communication language among various social groups in several districts in Bengkulu; and as an ethnic language, it is used by the people of Bengkulu City as a language of custom (Halim, 2004, pp. 251-255).

Bengkulu Malay has 25 phonemes with details of 6 vowel phonemes and 19 consonant phonemes, 2 (two) diphthong phonemes, and 5 (five) consonant clusters (clusters) (Hardiah, 2014, p. 348) and (Tarino, 2008, pp. 1-3) it has the word classes, such as nouns (selop, sikek, kelapo), adjective (sego, kere, jele, ceme, bulek, ), verbs (panggang, lari, tepelanting) pronoun(sayo, nyo, dio) numeralia (tigo, empek, duo bele). In this paper, the thing that is going to be discussed is clitics -lah (form, characteristic, and use of -lah) in constructing swear of Bengkulu-Malay Language which is explained in Bahasa Indonesia's word classes in the verb class.

The verb word is a word which only has grammatical meaning and has no lexical meaning. The meaning of the verb word is not determined by its own wprd loosely, but with its relation to the other word in a phrase or sentence (Alwi, 2003, p. 
287). the verb word class is a closed class while the open word class can easily for us to attach a word or accept another substance as a new word or as a synonym to the existed words befor.

The verb word based on its role in a phrase or clause, can be divided into five groups, they are: 1). Preposition 2). Conjunctor 3). Interjection 4). Articula 5). Enforcing particles. Preposition is called as preposition word, conjunctor is called as conjunction word, interjection is called as the emphasis word, articula is called as the verb word, and the enforcing particles which is a word with has no changing of form and its function only to display the substance which is attached to its own word (Alwi, 2003, pp. 288-307).

The characteristic of verb word is mostly all of the verb word can not use as a base to form a new word. From the verb datang, we can change into mendatangi, but it can not be done to the verb word. The verb word only has grammatical meaning if there is a relation to the other word in a phrase or clause. In the adjective manis, we can directly give the meaning based on its own word, but in the verb word, we can not do the same. The verb word $k e$ will have a meaning if it is attached to the other word to make a new word, for example ke kampus.

There are four kinds of enforcing particles, they are: -kah,-lah, -tah, and -pun. The particle -kah is an enforcing particles in a form of clitics, has a classical characteristic so it can give more pressure on interrogative sentence. The particle -tah which is in a form of clitics, is used in interrogative sentence, but the questioner expects no answer. The particle -pun is only used in a declarative sentence and in a written form is separated with the previous word. And the particle -lah is in a form of clitics too (Alwi, 2003, hal. 307-308).

Clitics is a bound form which phonologically has no own pressure and which can not be considered as a bound morpheme because it can fill phrase at the level of a phrase or clause, but has no word characteristics since it can not act as a free form (Kridalaksana H. , 1993, p. 113) it is also explained by (Verhaar, 2006) that clitics is as the shortest morphemes-at most two syllables, is usually one; can not be given any accent or pressure; attached to another word or phrase; and contains a meaning that is not easily described lexically. Clitics is also not bound to a particular word class, as usually there is an attachment to the bound morphemes.

The are two forms of clitics, they are enklitik and prokilitik.Enklitik is a clitic which is bound to the previous substance, for example -lah in pergilah. While proklitik is a clitic which is bound to the followed word of itself, for example ke in ke rumah. In clitics -lah is tend to be enklitik.

According to (Alwi, 2003, hal. 307-308) clitics -lah is used in imperative or declarative sentence. The rule of use in the imperative sentence is used to slightly refine the tone of the command, seen onBawa mobil ini ke bengkel besok pagi! will slightly refine the tone of the command if the construction Bawalah mobil ini ke bengkel besok pagi!. In a declarative sentence, -lah is used to give stronger pressure in the sentence, can be seen on Dia yang menggugat soal itu becomes Dialah yang menggugat soal $i t u$.

Bengkulu-Malay Language has the form of $l a$ and -lah, both of them have the difference form and meaning of itself. Though the pronunciation of it sometimes with the same tone. Compare to the constructions below:

(1) La segedang iko sayo belum jugo apal.

"I have been already an adult, but I can memorize it all"

(2) Apo kendak kau, pagi-pagi buto la menangis.

"what do you want to do, it is early in the morning, you have already cried"

(3) Kalu endak barangko baoklah kek kau.

"If you want this thing, please bring it with you"

(4) Maro berentilah berenyeng panjang kau ko, malu pulo dekek orang.

"please stop fighting you all, be embarrassed to the people"

The form la in construction (1) and (2) means 'already' is a word form whereas in construction (3) and (4) is clitics.

The data of swear in Bengkulu-Malay Language which have found by the researcher has clitics -lah, for example in a sentence below:

(5) Mati beranaklah kau! 'you'll die when you give a birth to your baby!' below (6):

The form of (5) is a swear in cursing to someone which has the clitics -lah. It is different to the sentence construction

(6) Mati beranak kau! 'die in giving birth to your baby' 
It has no clitics -lah so the researcher was interested to investigate clitics -lah in swear of Bengkulu-Malay Language from the form, characteristic and its used.

Swear is defined as a vile word spoken for anger and so on (http://www.kbbi.web.id, 2017). Swear also means the prohibition of using certain words, for fear or for the sake of politeness(Kridalaksana H. , 1993). based on those opinions, then the terminology of swear in Bengkulu-Malay Language is expressing (speak) the impolite words (abusive, rough-purposed, and so on) as the outlet form of anger or irritated. The expressive expression serves emotively for the liberation of all forms and situations because of anger, resentment, irritated, annoyance, or disappointment by using abusive, rough-purposed, objective censure with satire, or for intimacy purposes. The source of the swear was taken from the abusive word (Kau keparat), roughpurposed (didik nian lah), objective censure with satire (nyo batu bulek idak besending), or for intimacy purposes (oi bundung siko dulu, apo crito kini)(Rustinar, 2017, pp. 78-79).

\section{METHOD}

Methods is an orderly and well thought-out way to achieve purpose; a systematic way of working to facilitate the implementation of an activity in achieving the objectives specified (Djajasudarma \& Citraresmana, 2016, p. 1). The method of this research is qualitative method that is the procedure that produce descriptive data in the form of writing data. Qualitative research method is more concerned with the process than the results, the role of the process will be more clearly examined through the relationship of the parts. This is closely related to the method of nature-based distributional studies in line with the understanding of Ferdinand De Saussure's theory of the whole unified structural theory and clitics analysis as part of the word class is more concerned with the process in its analysis(Djajasudarma \& Citraresmana, 2016, p. 27).

The source of the data comes from libraries reference which were derived from three(3) sources. They were: books (Tarino, 2008); article (Botifar, 2016); and electronic media (Facebook, 2017).Datas were clitics -lah in constructing swear of Bengkulu-Malay Language.

Methods and techniques of data collection is done through the method of referring to writing techniques and methods of introspection by using the language intuition as a mother tongue (Muhammad, 2011, pp. 194-195); (Mahsun, 2014, pp. 92-104)

Data analysis was done through agih or distributional method which used the basic language determinant device (power of dividing) and even unity with the data itself(Djajasudarma \& Citraresmana, 2016, p. 49); (Muhammad, 2011, p. 244); (Sudaryanto, 2015, p. 18) which is used a device to determine the basic of language. The base of determining in a distributional method works is data selection techniques based on certain categories (criteria) in terms of programmatic because it divides the lingual unit of data into several parts or elements; and the elements concerned are viewed as directly forming the lingual unit in question with the device (power of dividing) and it also has a characteristic of lingual intuition (Sudaryanto, 2015, p. 37)

\section{FINDING AND DISCUSSION}

The result of the research showed that there were 15 data which used clitics -lah in constructing swear of BengkuluMalay Language. They were:

(1) Paju abarlah kau

(2) Ditembak petuslah kau

(3) Mati sepegaslah kau

(4) Mati beranaklah kau

(5) Mati berantulah kau

(6) Paju guamlah mulut ambo

(7) Paju rimaulah

(8) jahanamlah kau

(9) Masuk nerako jahanamlah kau

(10) buncitlah perut kau makan hak anak yatim iko

(11) Tekutuklah kau

(12) Mampuslah kau cepek,

(13) Modarlah kau Leke

(14) Sumpah dipaju gerindinlah kau

(15) Terbang amburlah dari rumah iko

The form of -lah in constructing swear of Bengkulu-Malay Language always bound in another form of word, so it could be defined that -lah is not an afix and is also not a word but it is called as clitics because it could not stand alone by itself. And it is called as clitic itself.

The function of clitics -lah is as a displayer of substance which is in it word itself with the characteristics, such as: 
1. clitics -lah can not stand alone.

2. clitics -lah have no meaning.

3. clitics -lah are bound to the element that precedes it.

4. clitics -lah appear alongside the form it attaches and plays as an enklitik.

5. clitics-can be attached with more than one word class.

The used of clitics -lah in the sentence construction of Bengkulu-Malay Language is as a pressure if it is attached to the other word. It can be seen from the comparison between swear construction of Bengkulu-Malay Language below:

mati beranak! 'die in giving birth to a baby'

Mati beranaklah kau! 'You'll die when you give birth to your baby!"

In a sentence of mati beranak is a cursing swear. The declarative swear itself will be more abusive after it is attached clitics -lah becomes Mati beranaklah kau!.

clitics -lah can also put pressure on pronouns where the person's pronoun is in front of the swear sentence, for example:

\section{Tekutuk kau!}

Tekutuklah kau!

In the sentence Tekutuk kau! the pressure is on the second singular person pronoun. kau 'you' refers to the person whom it is addressed as a hearer. It can be clearly seen the more pressure on the hearer from the sentence Tekutuklah kau!. And in the sentence Paju guamlah mulut ambo! The first singular person pronoun ambo 'I' can be seen in the swear paju guamlah faces the pressure on the first singular person pronoun which refers to the speaker itself.

From the used of clitics -lah can be seen that clitics is tend to be attached to the predicate of the sentence. It can be seen in these constructions:

\section{$\frac{\text { Jahanamlah kau }}{\mathrm{P}}$}

Or

$$
\begin{array}{cc}
\text { Tekutuklah kau! } \\
\mathrm{S} \quad \mathrm{P}
\end{array}
$$

\section{CONCLUSION}

-Lah is a form which is usually attached to the other form (word) then it can be said that -lah is not an affix and word but a clitics. - Lah in the swear of Bengkulu-Malay Language is not a wprd because -lah can not stand alone by itself.

The function of clitics -lah is as a displayer of substance which is in it word itself with the characteristics, such as;

1. clitics -lah can not stand alone.

2. clitics -lah have no meaning.

2. clitics -lah are bound to the element that precedes it.

3. clitics -lah appear alongside the form it attaches and plays

as an enklitik.

4. clitics-can be attached with more than one word class.

From the used of clitics -lah can be seen that clitics is tend to be attached to the predicate of the sentence. The used of clitics -lah in the sentence construction of Bengkulu-Malay Language is as a pressure if it is attached to the other word. In Bengkulu-Malay Language, the swear which is followed by clitics -lah made it becomes more abusive. clitics -lah can also put pressure on pronouns where the person's pronoun is in front of the swear sentence.

\section{References}

Alwi, H. S. (2003). Tata Bahasa Baku Bahasa Indonesia. Jakarta: Balai Pustaka.

BadanBahasa. http://badanbahasa.kemdikbud.go.id/peta bahasa. Retrieved oktober 20, 2017.

Bengkulu, B. P. (2017, Oktober 15). Badan Pusat Statistik Propinsi Bengkulu. Bengkulu,

mana, E. (2016). Metodologi dan Strategi Penelitian Linguistik. Bandung: Fakultas Ilmu Budaya Unpad.

Djajasudarma, T. F. (1997). Analisis Bahasa (Sintaksis dan Semantik). Bandung: Humaniora Utama Press.

Facebook. (2017, april-agustus -). Komunitas Peduli Baso, Seni, dan Budaya Bengkulu. Kota Bengkulu, Bengkulu, Indonesia. 
Halim, A. (2004). Bahasa Melayu Bengkulu dalam Kaitan dengan Bahasa Indonesia. dalam (Bunga Rampai Melayu Bengkulu): Dinas Pariwisata Propinsi Bengkulu.

Hamidy, B. M. (2004). Masuk dan Berkembangnya Islam di Daerah Bengkulu dalam (Bunga Rampai Melayu Bengkulu): Dinas Pariwisata Propinsi Bengkulu.

Hardiah, M. (2014). Fonologi Bahasa Melayu Bengkulu. (Kongres Internasional Masyaratakat LInguistik Indonesia)-KIMLI , 344-348.

http://www.kbbi.web.id. (2017, oktober 15). Kamus Besar bahasa Indonesia Versi Daring. Retrieved oktober 15, 2017, from http://www.kbbi.web.id: http://www.kbbi.web.id

Kridalaksana, H. (1993). Kamus Linguistik. Jakarta: Gramedia Pustaka Utama.

Mahsun, M. (2007). Metode Penelitian Bahasa. Jakarta: Rajagrafindo Persada.

Moleong. (2011). Metode Penelitian Bahasa. Jakarta: Rajagrafindo Persada.

Muhammad. (2011). Metode Penelitian Bahasa. Yogyakarta: Ar-Ruzz Media.

Rustinar, E. (2017). Fenomena Makian di Era Digital. Konferensi Nasional Sastra, Bahasa, dan Budaya 2017 (pp. $77-86$ ). Malang: Fak.Bahasa dan Sastra Univ.Kanjuruhan Malang.

Rustinar, E. (2017). Swear Bengkulu-Malay Language. Abstrak The 1th International Seminar of Language, Literature, and Education ISBN: 978-602-61994-0-9 (pp. 57-58). Jakarta: Perkumpulan Program Studi Pendidikan Bahasa dan Sastra Indonesia (IKAPROBSI).

Saussure, F. d. (1996). Pengantar Linguistik Umum (terjemahan). yogyakarta: Gadjah Mada University Press.

Sudaryanto. (2015). Metode dan Aneka Teknik Analisis Bahasa. Yogyakarta: Universitas Sanata Dharma .

Susiyanto. (2005). Ethnic Interaction In Etnicity Framework (Interaksi Antar Etnik dalam Kerangka Etnisitas) Disertasi. Bandung: Unpad.

Tarino, O. (2008). Pernak-Pernik Bahaso Melayu Bengkulu. Bengkulu: belum diterbitkan.

Verhaar, J. (2006). Asas-asas Linguistik Umum. Yogyakarta: Gadjah Mada University Press.

Wijana, I. D. (2011). Sosiolinguistik (Kajian Teori dan Analisis). Yogyakarta: Pustaka Pelajar. 